\title{
THE RELATIONSHIP BETWEEN MENTAL HEALTH LITERACY AND STIGMA MENTAL DISORDERS IN THE SOKO VILLAGE COMMUNITY, BAGELEN DISTRICT, PURWOREJO REGENCY
}

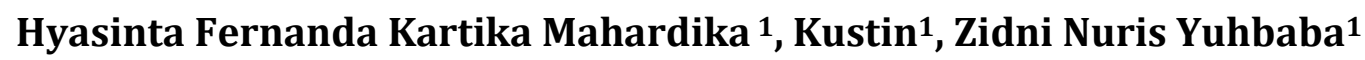

${ }^{1}$ Nursing Science Programme, Faculty of Health Science, Universitas dr. Soebandi, East Java, Indonesia *Corresponding author e-mail: kustinhariyono@gmail.com

\begin{abstract}
One of the significant health problems in the world, including in Indonesia, is mental health. Data from the Ministry of Health research conducted every five to six years regarding public health figures shows that the number of people with mental health problems in Indonesia needs serious treatment. The purpose of this study was to determine the relationship between Mental Health Literacy and Stigma Mental Disorders. This research is a correlation study using data collection techniques in the form of the Mental Health Knowledge Questionnaire (MHKQ) and the Peer Mental Illness Stigmatization Scale (PMISS). The research subjects were 52 using simple random sampling technique. Based on the results of the analysis showed that the correlation coefficient between mental health literacy and the stigma of mental disorders was 0.086 with a significance of 0. 542. The significance number in the results of this study exceeds the predetermined significance number, which is $>0.05$. This means that there is no relationship between mental health literacy and the stigma of mental disorders. For further research, it is necessary to conduct further research on mental health literacy in the community in order to know the impact that can be caused on the stigma of mental disorders.
\end{abstract}

Keywords: Mental Health Literacy, Stigma Mental Disorder, Age 20-70

\section{INTRODUCTION}

One of the significant health problems in the world, including in Indonesia, is mental health. From the Ministry of Health research data conducted every five to six years regarding public health figures, it shows that the number of people with mental health problems in Indonesia needs serious treatment ${ }^{1}$. In the world there are about 792 million people or $10.7 \%$ of people with mental disorders (ODGJ). Mental disorders and the use of any substance occupy the highest prevalence of $13 \%$ while anorexia and bulimia are $0.2 \%{ }^{2}$. Based on Riskesda data in 2013 and 2018, it was stated that the prevalence of severe mental disorders in Indonesia was 
$1.7 \%$ and $7.0 \%$, respectively. The highest prevalence is in the provinces of Aceh and DIY at $2.7 \%$ and the lowest is in the province of West Kalimantan at $0.7 \%{ }^{3}$. Meanwhile, in 2018 the highest prevalence was in the province of Bali at $11 \%$ and the lowest in the province of the Riau archipelago at 3\% (Riskesdas, 2018). Central Java province ranks fourth highest along with Aceh, South Sulawesi and West Sumatra with a prevalence of $9 \%$.

People who experience mental/mental disorders are often referred to in the general public as "crazy people", so they often experience unpleasant treatment, even in the wider community a negative stigma has been built up against people with mental disorders ${ }^{4}$. Stigma in the context of social life refers to the negative characteristics inherent in a person because they are considered tainted, have despicable or deviant behavior ${ }^{5}$. Stigma is an attitude or emotional reaction that appears in society to people with mental disorders by isolating or demeaning them ${ }^{6}$. Mental disorders are not the result of social deviations or conflicts with society, but are psychological or behavioral patterns shown in individuals who show distress, decreased quality of life and dysfunction ${ }^{7}$.

Mental Health Literacy is knowledge and beliefs about mental disorders that help for the recognition, management, and prevention of mental health disorders. So mental health literacy is not only providing knowledge about mental disorders, but also allows this knowledge to bring up real behaviors that can help themselves and others in terms of mental health ${ }^{8}$. Socialization and counseling to families and communities about mental disorders is very necessary to eliminate wrong views about mental disorders. Besides that, as soon as possible handling of people with mental disorders and socializing to families and communities how they should behave towards people with mental disorders. For this reason, it is necessary to have the participation of the community in order to create a prosperous society.

\section{METHODS}

The type of research used in this study is quantitative correlation with a cross sectional approach. The population in this study was 1 person/KK as many as 60 people in RT 01 RW 04 Soko Village, Bagelen District, Purworejo Regency. The sample in this study were 52 people. The data collection tools in this study were questionnaires, namely the Health Literacy Questionnare and the Peer Mental Illness Stigmatization Scale. This study was used to examine the relationship between mental health literacy and the stigma of mental disorders.

\section{RESULTS}

The research was conducted in RT 01 RW 04 Soko Village, Bagelen District, Purworejo Regency with 52 respondents involved. 
Table 1. Characteristics of Respondents

\begin{tabular}{lc}
\hline \multicolumn{1}{c}{ Characteristics of Respondents } & $\mathbf{N}(\%)$ \\
\hline Gender & $17(32.7)$ \\
\hline Man & $35(67.3)$ \\
Woman & \\
\hline Age & $18(34.6)$ \\
\hline $20-39$ years old & $24(46.2)$ \\
$40-59$ years old & $10(19.2)$ \\
60 years & \\
\hline Profession & $19(36.5)$ \\
\hline Housewife & $4(7,7)$ \\
Farmer & $5(9.6)$ \\
Private & $3(5.8)$ \\
Teacher & $2(3.8)$ \\
College student & $3(5.8)$ \\
Trader & $2(3.8)$ \\
Laborer & $2(3.8)$ \\
Retired & $12(23.1)$ \\
\hline Etc & \\
\hline
\end{tabular}

Of the total 52 respondents who took part in this study, $32.7 \%$ male respondents were 17 people and $67.3 \%$ were female. That is 35 people. Characteristics of respondents based on age were divided into 3 categories, namely age 20-39 years, 40-59 years and 60 years. Based on Table 1, it is known that respondents aged 34.6\%, namely 18, respondents aged 40-59 years were $46.2 \%$, namely 24 , and respondents aged 60 years were $19.2 \%$. Namely 10 . In this study, most of the respondents were aged 20-39 years, as many as 81 respondents $(34.6 \%)$.

Based on the occupation, the characteristics of the respondents in this study were divided into 9 types of work. These jobs consist of housewives, farmers, private sector, teachers, students, traders, laborers, retirees, and other jobs. The number of housewives respondents is $36.5 \%$, the number of farmer respondents is $7.7 \%$, the number of private respondents is $9.6 \%$, the number of teachers and traders respondents is $5.8 \%$, the number of student respondents, laborers, and retirees is $3.8 \%$, and the number of respondents with other jobs is $23.1 \%$.

Table 2. Minimum value, maximum value, mean, and standard deviation

\begin{tabular}{lccccc}
\hline Variable & Min Value & Max Value & Average & $\begin{array}{c}\text { Standard } \\
\text { Deviation }\end{array}$ \\
\hline Mental Health Literacy & 12 & 27 & 23.48 & 3.31 \\
Stigma of Mental & 2 & 13 & 6.94 & 2.53 \\
Disorders & & & & \\
\hline
\end{tabular}


It was found that the smallest score (minimum) on the mental health literacy variable was 12 and the largest score (maximum) was 27. The average value was 23.48 and the standard deviation was 3.31. Meanwhile, the stigma variable for mental disorders has the smallest (minimum) score of 2 and the largest (maximum) score of 13.00 with an average value of 6.94 and a standard deviation of 2.53 .

Table 3. The results of the analysis of the stigma of mental disorders by category

\begin{tabular}{cccc}
\hline Variable & Category & $\begin{array}{c}\text { Number of } \\
\text { Respondents }\end{array}$ & $\begin{array}{c}\text { Percentage } \\
\text { (\%) }\end{array}$ \\
\hline Mental health & Low & 0 & 0 \\
literacy & Currently & 3 & 5.8 \\
& Tall & 49 & 94.2 \\
Stigma of mental & Low & 12 & 23.1 \\
disorders & Currently & 35 & 67.3 \\
& Tall & 5 & 9.6 \\
\hline
\end{tabular}

Based on the results of the analysis in Table 5.3 it was found that the results of the analysis of mental health literacy in the medium category were $5.8 \%$ and in the high category were $94.2 \%$. Mental health literacy in this study was dominated by high literacy, which was 49 respondents. Based on the stigma of mental disorders, the low category was $23.1 \%$, the medium category was $67.3 \%$, and the high category was $9.6 \%$. The majority of the stigma of mental disorders in this study were in the moderate category with a total of 35 respondents.

The correlation coefficient between mental health literacy and stigma of mental disorders is 0.086 with a significance of 0.542 . The significance number in the results of this study exceeds the predetermined significance number, which is $>0.05$. This means that there is no relationship between mental health literacy and the stigma of mental disorders in the people of Soko Village, Bagelen District, Purworejo Regency.

Table 4. The relationship between mental health literacy and the stigma of mental disorders

\begin{tabular}{clll}
\hline & & $\begin{array}{l}\text { Mental } \\
\text { Health } \\
\text { Literacy }\end{array}$ & $\begin{array}{l}\text { Stigma } \\
\text { Mental } \\
\text { Disorders }\end{array}$ \\
\hline Literacy & Correlation coefficient & 1,000 & 0.086 \\
Mental health & Sig. (2-tailed) & & 0.542 \\
& $\mathrm{~N}$ & 52 & 52 \\
Stigma & Correlation coefficient & 0.086 & 1,000 \\
Mental disorders & Sig. (2-tailed) & 0.542 & \\
\cline { 2 - 4 } & $\mathrm{N}$ & 52 & 52 \\
\hline
\end{tabular}




\section{DISCUSSION}

\section{Mental Health Literacy}

Based on the results of the study, it shows that mental health literacy in this study is categorized in high literacy. Mental health literacy is defined as knowledge and beliefs about mental disorders that help with recognition, management, and prevention ${ }^{8}$. The results of this study are in accordance which states that the results of adult mental health literacy are high ${ }^{9}$. The average value of mental health literacy is 73.08 (scale 100). Female respondents had a higher level of health literacy than male respondents but there was no significant difference $(p>0.05)$ between the two ${ }^{1}$. This result is better than the results of Widyana's research which found mental health literacy results for nursing students at the Muhammadiyah University of Surabaya, namely having moderate literacy ${ }^{10}$. This shows that the mental health literacy of the community in general is better than the mental health literacy possessed by students. This is presumably because in this study the age of the respondents was more diverse than the age of the respondents ${ }^{10}$. Therefore, the respondents in this study also had more experience in the form of mental health, so they had higher mental health literacy.As stated in the literature review, one of the factors of mental health literacy is gender. So a person's gender can affect the level of mental health literacy.

\section{Stigma of Mental Disorders}

The results of this study indicate that the stigma of mental disorders in this study is categorized as having moderate stigma. The stigma against people with mental disorders in Indonesia is still very strong. With this stigma, people with mental disorders are isolated and can worsen their mental disorders. The stigma of mental disorders in nursing students at the Muhammadiyah University of Surabaya was moderate. This is presumably because nursing students have better knowledge of mental disorders than the general public, so they have moderate stigma ${ }^{10}$. This result is in accordance with the literature review, namely the labeling theory factor. Socio-cultural theorists argue that when the label "mental illness" is used, it is very difficult to eliminate it. Labeling will affect how other people will respond to people with Mental Illness. With the term "mental illness" then other people stigmatize that person. So why is the stigma of mental disorders still high, because people will label people with mental disorders and the label will not be lost. The response to rejecting people with mental disorders is marked by discrimination in the form of stigma. Stigma is labeling, exclusion, and discrimination by a person or group so that it can limit people who are stigmatized in socializing so that it can complicate their lives.

\section{Relationship between Mental Health Literacy and Stigma of Mental Disorders}

Based on the results of the study, it showed that there was no relationship between mental health literacy and the stigma of mental disorders in the people of Soko Village, Bagelen District, Purworejo Regency. Mental health literacy and self-stigma have a weak correlation ${ }^{11}$. A negative and significant relationship between self-stigma and mental health literacy. These 
findings indicate that self-stigma, whether related to seeking help or mental disorders, is an important predictor of mental health literacy ${ }^{12}$.

\section{CONCLUSION}

It can be concluded that the people of Soko Village, Bagelen District, Purworejo Regency have a high level of mental health literacy, moderate level of mental disorder stigma. There is no relationship between Mental Health Literacy and Stigma Mental Disorders in the Soko Village Community, Bagelen District, Purworejo Regency.

\section{REFERENCES}

1. AZZAHRA SS. PERBEDAAN TINGKAT LITERASI KESEHATAN PADA RESPONDEN LAKILAKI DAN PEREMPUAN DI RS PKU MUHAMMADIYAH DAN APOTEK PANTI AFIAT YOGYAKARTA. Universitas Gadjah Mada; 2017.

2. Roser M, Ritchie H, Ortiz-Ospina E, Hasell J. Coronavirus Pandemic (COVID-19); 2020. Published online at OurWorldInData. org. 2021.

3. Ayuningtyas D, Rayhani M. Analisis situasi kesehatan mental pada masyarakat di Indonesia dan strategi penanggulangannya. J Ilmu Kesehat Masy. 2018;9(1):1-10.

4. Gani TA, Wahyuni P, Fahrina A. Antologi Dari Bumi Paguntaka: Perspektif Minda Akademia UBT. Syiah Kuala University Press; 2020.

5. Aulia S. My price is my life, Basuki Tjahaja Purnama, Dare to die for the constitution and fight corruption. Gramedia Pustaka Utama; 2016.

6. Zigler E, Phillips L. Psychiatric diagnosis and symptomatology. J Abnorm Soc Psychol. 1961;63(1):69.

7. Stuart GW, Laraia MT. Stuart \& Sundeen's principles and practice of psychiatric nursing. Mosby Incorporated; 1998.

8. Jorm AF. Mental health literacy: Public knowledge and beliefs about mental disorders. $\mathrm{Br}$ J Psychiatry. 2000;177(5):396-401.

9. Handayani T, Ayubi D, Anshari D. Literasi Kesehatan Mental Orang Dewasa dan Penggunaan Pelayanan Kesehatan Mental. Perilaku dan Promosi Kesehat Indones J Heal Promot Behav. 2020;2(1):9-17.

10. Nikmah Dwi Noer Widyana N. Hubungan antara Literasi Kesehatan Mental dengan Mental Illness Stigma pada Mahasiswa Keperawatan Universitas Muhammadiyah Surabaya. UIN Sunan Ampel Surabaya; 2019.

11. O'Keeffe D, Turner N, Foley S, Lawlor E, Kinsella A, O'Callaghan E, et al. The relationship between mental health literacy regarding schizophrenia and psychiatric stigma in the Republic of Ireland. J Ment Heal. 2016;25(2):100-8.

12. Crowe A, Mullen PR, Littlewood K. Self-stigma, mental health literacy, and health outcomes in integrated care. J Couns Dev. 2018;96(3):267-77. 